Psychological Medicine, 1990, 20, 11-22

Printed in Great Britain

\title{
EDITORIAL
}

\section{The genetic epidemiology of alcoholism ${ }^{1,2}$}

Alcoholism may constitute the major public health problem in many parts of the world. Its effects on morbidity and mortality have been grossly underestimated in world health statistics. Approximately $20-60 \%$ of all hospital admissions in the United States are related to consequences of alcohol. Moreover, if its secondary role in deaths due to homicide, suicide, accidents, and alcohol-related cancers is considered, it is the fourth leading cause of death in the United States (Institute of Medicine, 1987).

According to a recent large scale epidemiological survey of the United States adult population, alcoholism is the most prevalent psychiatric syndrome in the population (Robins et al. 1984; Myers et al. 1984). The lifetime prevalence of alcohol abuse or dependence was $14 \%$, with males having a six-fold greater risk than females (i.e. $24 \% v .4 \%$ ). At the time of the survey, $9 \%$ of males and $2 \%$ of adult females had met criteria for alcohol abuse or dependence during the past six months. Some studies suggest that there is a secular trend for alcoholism with higher rates in more recent birth cohorts (Reich et al. 1988). Despite these high rates, less than $10 \%$ of alcoholics in the general population have sought treatment specifically for alcoholism (Shapiro et al. 1984). This suggests that there may be substantial biases present in studies of alcoholics who derive solely from treatment settings or registries.

Alcohol research has been hampered by the lack of agreement on a valid definition of alcoholism. Because we have no presumptive diagnostic test for alcoholism, the diagnosis depends upon clinical signs and symptoms of the alcohol-related behaviour. Traditional definitions of alcoholism have been based upon assessment of the consequences of the use of alcohol. The circularity of this conceptualization has been well demonstrated. Although persons suffering from severe medical or social consequences of alcohol are likely to have the condition, a substantial proportion of persons with the condition may escape its consequences because of factors unrelated to the disorder itself.

Recent standardized classification systems have now attempted to separate alcohol-seeking behaviour and its physiological concomitants from the social, psychological, and physical consequences of such behaviour, as suggested by Edwards \& Gross (1976). The draft of the ICD10 separates two syndromes of use of alcohol as follows: hazardous use, characterized by an occasional, repeated, or persistent pattern of use of alcohol which carries with it a high risk of causing future damage to the medical or mental health of the user, but which has not yet resulted in significant medical or psychological ill effects; harmful use, characterized by a pattern of use that is already causing health damage. The alcohol use syndromes, which are chiefly comprised of consequences of alcohol, are further distinguished from the Dependence Syndrome which requires evidence of craving or compulsive alcohol-seeking behaviour, tolerance, or withdrawal.

The most recent diagnostic classification system of the American Psychiatric Association, the Diagnostic and Statistical Manual-III-R, has similarly distinguished between alcohol abuse and dependence (American Psychiatric Association, 1987). Whereas alcohol abuse comprises a maladaptive pattern of alcohol use over a one-month period, alcohol dependence focuses on alcohol-seeking behaviour, craving, tolerance and withdrawal. Adoption of these criteria should help to reduce the variability in the genetic studies that will be reviewed below. Most of these studies have used a broad definition of alcoholism, which did not require craving for alcohol, tolerance or withdrawal, and in some subjects may solely derive from social or psychological consequences of alcohol use.

\footnotetext{
' Presented at the International Symposium on the Genetics of Neuropsychiatric Diseases, The Wenner-Gren Centre, Stockholm, Sweden, 28 May 1988

2 Address for correspondence: Dr Kathleen R. Merikangas, Departments of Psychiatry and Epidemiology, Genetic Epidemiology Research Unit, Yale University School of Medicine, 40 Temple Street, Lower Level, New Haven, Connecticut, 06510, USA.
} 
There are numerous methodological issues which continue to impede research in alcoholism. As described above, the lack of agreement between studies on the definition of alcoholism limits the comparability of studies. Furthermore, those definitions which solely depend upon consequences of alcohol-related behaviour may lead to biased estimates of rates of alcoholism.

Probands in most existing studies of alcoholism, who have been ascertained from treatment studies, represent the tip of the iceberg of alcoholism in the population. Because only a small proportion of persons seek treatment or come to the attention of the authorities for alcohol-related behaviour, the generalizability of the results of studies in which the sampling source is comprised of treatment or temperance board registries may be limited and subject to unknown biases (Shapiro et al. 1984).

Another aspect of alcoholism which requires methodological attention is the variable age of onset, which extends from the mid-to-late teens until beyond the age 50 . Recent evidence suggests a decrease in the average age of onset of alcoholism, particularly among women (Reich et al. 1988). Accurate dating of the age-of-onset is impeded by the insidious onset of the disorder and the arbitrary decision regarding the point at which riormal drinking behaviour becomes problematical. Moreover, sex differences in the risk period have rarely been considered in studies of this condition. Reich et al. (1988) have shown that the age-of-onset and lifetime population prevalence of alcoholism among women are becoming increasingly similar to those of men.

Co-morbidity with other psychiatric conditions has also complicated the interpretation of studies of the epidemiology and genetics of alcoholism. Numerous disorders co-occur with alcoholism in both clinical and epidemiological populations. Whereas $32 \%$ of the general population meets criteria for a second core diagnosis, $47 \%$ of alcinolics meet criteria for a second diagnosis, many of which are heritable. Alcoholism is specinicaliy associated with the following disorders in the epidemiological catchment area study (ECA) of adults in the US: antisocial personality (odds ratio $=21.0$ ); drug dependence (odds ratio $=11.2$ ); mania (odds ratio $=6.2$ ); schizophrenia (odds ratio $=4.0$ ); drug abuse (odds ratio $=3.9$ ); panic disorder (odds ratio $=2.4$ ); and major depression (odds ratio $=1 \cdot 7$ ) (Helzer \& Pryzbeck, 1988). With such co-morbid disorders, it is difficult to discriminate cause from consequence, or order of presentation of each condition with the use of retrospective diagnoses.

Genetic analyses of alcoholism are often complicated by the simultaneous presence of several disorders within families and individuals. The high prevalence of the major psychiatric disorders in the general population elevates the probability that co-occurrence of such disorders may be a chance phenomenon. Therefore, decisions to include an associated condition under affected status should be based upon a priori evidence that the two conditions co-segregate, or represent manifestations of the same underlying factors within families. Genetic analyses of several alternative combinations of these disorders without evidence for a transmissible association between them violates the prior assumptions of both segregation and linkage analysis.

The high rate of polysubstance abuse constitutes a similar problem to that of co-morbidity of alcoholism with other psychiatric conditions. Abuse of cocaine, sedatives, opiates, hallucinogens, and amphetamines is strongly associated with alcoholism, with odds ratios exceeding 10 for all of these substances (Helzer \& Pryzbeck, 1988). Furthermore, the association between nicotine and alcohol abuse is often neglected, particularly in biological studies of alcoholism (Kaprio et al. 1981).

Finally, the phenomenon of non-random mating, either assortative or disassortative, presents a major barrier to the determination of the mode of inheritance of alcoholism. Assortative mating systems affect the genotypic distribution in the population by increasing the proportion of homozygous individuals and in decreasing the proportion of heterozygotes. As many as 40-50\% of alcoholics in some series have been found to have a spouse with either alcoholism, antisocial personality, major depression, or an anxiety disorder (Merikangas, 1982; Jacob \& Bremer, 1986; Reich et al. 1988). Furthermore, offspring of dual matings have usually been found to have elevated risk of alcoholism beyond that conveyed by a single parent with alcoholism. This phenomenon complicates studies of familial transmission and renders a large proportion of families uninformative for linkage studies.

There are four major research areas of genetic studies of alcoholism in humans including: familial 
transmission; association and linkage of alcoholism with biological markers; vulnerability studies; and characterization of alcohol metabolizing enzymes. The major findings from each of these study domains will be reviewed below.

\section{FAMILIAL TRANSMISSION OF ALCOHOLISM}

The familial nature of alcoholism has been known for centuries. Aristotle, Plato, and Plutarch all described the tendency for the drinking behaviour of children to resemble that of their parents (Warner \& Rosett, 1975). The mechanism for familial transmission was attributed to the effect of alcohol on the parental germ cells, thereby leading to degeneracy in the resulting offspring. Social explanations for familial aggregation did not arise until the early part of this century (Goodwin, $1979 ; 1987)$.

\section{Family studies}

Although there have been more than 40 family studies of alcoholism (for a review, see Cotton, 1979), there are only a limited number of studies that have conducted direct interviews with probands and their relatives, employed standardized diagnostic criteria, and included a control group which was assessed with similar diagnostic methods to those of the group of probands. These studies are shown in Table 1. The results show that there is an average seven-fold increase in the risk of alcoholism among the first degree relatives of probands as compared to controls. One quarter of the fathers and $5 \%$ of the mothers of probands with alcoholism also have alcoholism. The relative risk of illness is consistently greater in male than in female relatives, in proportions of the same magnitude as those reported in epidemiological studies. The only three studies that reported the risk to relatives according to the sex of the proband showed no sex difference in the transmission of alcoholism to first-degree relatives, thereby indicating that the sex difference in alcoholism cannot be attributed to transmissible genetic factors (Guze et al. 1986; Reich et al. 1975). Therefore, the lower rates of alcoholism in females may be attributed to environmental factors such as exposure, or differences in background genetic or biological factors such as hormonal factors which are unique to women.

The study of Bleuler in 1955 constitutes one of the most carefully designed family studies of alcoholism by systematically assessing first- and second-degree relatives including half-siblings of cases and controls. This study showed a strong degree of familial aggregation in first degree relatives of cases as compared to controls. The finding of approximately $1 / 2$ the risk in second-degree

Table 1. Controlled family studies of alcoholism

\begin{tabular}{|c|c|c|c|c|c|c|}
\hline \multirow[b]{2}{*}{ Author (year) } & & \multirow[b]{2}{*}{ Subjects } & \multirow{2}{*}{$\begin{array}{l}\text { First degree } \\
\text { relatives }\end{array}$} & \multicolumn{2}{|c|}{ Recurrence risk $(\%)$} & \multirow{2}{*}{$\begin{array}{l}\text { Relative } \\
\text { risk }\end{array}$} \\
\hline & & & & Probands & Controls & \\
\hline Brugger (1933) & $\begin{array}{r}119 \\
1300\end{array}$ & $\begin{array}{l}\text { Tx } \\
\text { Controls }\end{array}$ & $\begin{array}{l}\text { Parents } \\
\text { Siblings }\end{array}$ & $\begin{array}{l}29.8 \\
11 \cdot 0\end{array}$ & $\begin{array}{l}9 \cdot 1 \\
1 \cdot 2\end{array}$ & $\begin{array}{l}3 \cdot 2 \\
9 \cdot 1\end{array}$ \\
\hline Amark (1951) & $\begin{array}{r}203 \\
85\end{array}$ & $\begin{array}{l}\text { Male, Tx } \\
\text { Male Controls }\end{array}$ & $\begin{array}{l}\text { Fathers } \\
\text { Mothers }\end{array}$ & $\begin{array}{r}26 \cdot 2 \\
2 \cdot 0\end{array}$ & $\begin{array}{l}3 \cdot 4 \\
0 \cdot 1\end{array}$ & $\begin{array}{r}7.7 \\
20 \cdot 1\end{array}$ \\
\hline Bleuler (1955) & $\begin{array}{r}50 \\
200\end{array}$ & $\begin{array}{l}\mathrm{Tx} \\
\text { Controls }\end{array}$ & $\begin{array}{l}\text { Fathers } \\
\text { Mothers } \\
\text { Brothers } \\
\text { Sisters }\end{array}$ & $\begin{array}{r}22.0 \\
6.0 \\
11.8 \\
8.0\end{array}$ & $\begin{array}{l}3.0 \\
1.0 \\
1.3 \\
0.7\end{array}$ & $\begin{array}{r}7.3 \\
6.0 \\
9.0 \\
11.4\end{array}$ \\
\hline Pitts \& Winokur (1966) & $\begin{array}{r}62 \\
428\end{array}$ & $\begin{array}{l}\text { Tx } \\
\text { Controls }\end{array}$ & $\begin{array}{l}\text { Fathers } \\
\text { Mothers } \\
\text { Brothers } \\
\text { Sisters }\end{array}$ & $\begin{array}{r}16.1 \\
1.6 \\
12.4 \\
1.0\end{array}$ & $\begin{array}{l}4.9 \\
0.6 \\
2 \cdot 0 \\
0.4\end{array}$ & $\begin{array}{l}3 \cdot 3 \\
2 \cdot 7 \\
6 \cdot 2 \\
2 \cdot 5\end{array}$ \\
\hline Reich et al. (1980) & $\begin{array}{l}74 \\
57 \\
32\end{array}$ & $\begin{array}{l}\text { Tx } \\
\text { Parole } \\
\text { Controls }\end{array}$ & $\begin{array}{l}\text { Parents and } \\
\text { siblings } \\
\text { Grandfathers }\end{array}$ & $\begin{array}{l}35 \cdot 6 \\
11 \cdot 0\end{array}$ & $\begin{array}{r}12 \cdot 1 \\
4 \cdot 7\end{array}$ & $\begin{array}{l}2 \cdot 9 \\
2 \cdot 3\end{array}$ \\
\hline
\end{tabular}


relatives including grandfathers and uncles as compared to fathers and brothers, and grandmothers and aunts as compared to mothers and sisters, is compatible with traditional Mendelian patterns. However, the risk to both male and female half-siblings was greater than that to full brothers and sisters.

There are several possible explanations for this finding. Half-siblings, who derive from the dissolution of families, may be at increased risk for development of alcoholism because of clustering of environmental precipitants of alcoholism. Alternatively, it is clear that there is a dramatic increase in rates of alcoholism among the co-parents of the half-siblings, who are non-biological relatives, over that in the control population. Whereas rates of alcoholism among the control fathers and mothers were 3 and $1 \%$ respectively, rates of alcoholism in the spouses were 29 and $16 \%$ for husbands and wives. These latter rates are remarkably similar to those described nearly three decades later by Reich et al. (1980) who found alcoholism in $39 \%$ of the husbands and $18 \%$ of the wives of alcoholic probands.

Very few data are available from controlled family studies on the risk to second degree relatives of alcoholic parents. Reich et al. (1980) found a four-fold increase in rates of alcoholism among grandfathers of male alcoholics (i.e. 16\%) compared to those of controls (i.e. $5 \%$ ). Moreover, the rates of alcoholism among female alcoholics' grandfathers of $4 \%$ were similar to those of the controls. Kaij \& Dock (1975) reported equal rates of alcoholism in the grandsons of alcoholic grandmothers versus those of alcoholic grandfathers, the risk for each being $46 \%$. However, because no data on controls were presented, computation of the relative risk for second degree relatives was not possible. In a study of half-siblings of alcoholic young men, Schuckit et al. (1972) found equal risk to full and half-siblings of probands. Equal rates in the first and second degree relatives are inconsistent with virtually any genetic model, thereby providing evidence for the importance of environmental factors in the aetiology of alcoholism.

\section{Twin studies}

There have been five studies of twins selected from registries of normal twins to assess alcoholrelated behaviour (Table 2). The average correlation between monozygotic twins was significantly greater (i.e. 0.54 , range $0.37-0.56$ ) than that among dizygotic twins (i.e. 0.23 , range $0-0.50$ ). The average heritability was 0.50 for quantity and 0.40 for frequency of drinking. The average heritability for females was greater than that for males, but females were only assessed in two studies.

The heritability for frequency of drinking $(40 \%)$ was higher than for amount of consumption per

Table 2. Adult twin studies of alcoholism: I twin registries

\begin{tabular}{|c|c|c|c|c|c|c|}
\hline \multirow[b]{2}{*}{ Author (year) } & \multirow[b]{2}{*}{ Subjects } & \multirow[b]{2}{*}{ Sex } & \multicolumn{2}{|c|}{ Correlation $(r)$} & \multicolumn{2}{|c|}{ Heritability $\left(h^{2}\right)$} \\
\hline & & & Quantity & Frequency & Quantity & Frequency \\
\hline Partanen et al. (1966) & $\begin{array}{l}172 \mathrm{MZ} \\
557 \mathrm{DZ}\end{array}$ & $\begin{array}{l}\mathrm{M} \\
\mathrm{M}\end{array}$ & $\begin{array}{l}0.38 \\
0.11\end{array}$ & $\begin{array}{l}0.61 \\
0.32\end{array}$ & 0.36 & 0.39 \\
\hline Jonsson \& Nilsson (1968) & $\begin{array}{l}750 \mathrm{MZ} \\
750 \mathrm{DZ}\end{array}$ & $\begin{array}{l}\mathrm{M} \\
\mathrm{M}\end{array}$ & $\begin{array}{l}0.43 \\
0.35\end{array}$ & $\overline{-}$ & 0.16 & - \\
\hline Clifford et al. (1984) & $\begin{array}{c}97 \mathrm{MZ} \\
102 \mathrm{DZ} \\
207 \mathrm{MZ} \\
165 \mathrm{DZ}\end{array}$ & $\begin{array}{l}M \\
M \\
F \\
F\end{array}$ & $\begin{array}{l}0.55 \\
0.50 \\
0.50 \\
0.25\end{array}$ & $\begin{array}{l}- \\
\overline{-} \\
-\end{array}$ & 0.28 & - \\
\hline Kaprio et al. (1987) & $\begin{array}{l}893 \mathrm{MZ} \\
1970 \mathrm{DZ}\end{array}$ & $\begin{array}{l}M \\
M\end{array}$ & $\begin{array}{l}0.37 \\
0.19\end{array}$ & $\begin{array}{l}0.36 \\
0.16\end{array}$ & 0.36 & 0.40 \\
\hline Pedersen (1981) & $\begin{array}{l}39 \mathrm{MZ} \\
32 \mathrm{DZ} \\
36 \mathrm{MZ} \\
30 \mathrm{DZ}\end{array}$ & $\begin{array}{l}M \\
M \\
F \\
F\end{array}$ & $\begin{array}{r}0.56 \\
0.15 \\
1.00 \\
-0.05\end{array}$ & $\begin{array}{l}- \\
\overline{-} \\
-\end{array}$ & $\begin{array}{l}0.82 \\
>1\end{array}$ & $\begin{array}{l}\text { (Heavy } \\
\text { drinking) }\end{array}$ \\
\hline
\end{tabular}


Table 3. Adult twin studies of alcoholism: II TX samples/registries

\begin{tabular}{|c|c|c|c|c|c|c|}
\hline \multirow[b]{2}{*}{ Author (year) } & \multicolumn{2}{|c|}{ Subjects } & \multicolumn{2}{|c|}{ Concordance (\%) } & \multicolumn{2}{|c|}{ Relative risk } \\
\hline & Male & Female & Male & Female & Male & Female \\
\hline Kaij (1960) & $\begin{array}{r}10 \mathrm{MZ} \\
164 \mathrm{DZ}\end{array}$ & - & $\begin{array}{l}58 \\
28\end{array}$ & - & $2 \cdot 1$ & \\
\hline Hrubec \& Omenn (1981) & $\begin{array}{l}271 \mathrm{MZ} \\
444 \mathrm{DZ}\end{array}$ & - & $\begin{array}{l}26 \\
12\end{array}$ & - & $2 \cdot 1$ & \\
\hline Gurling et al. (1981) & $\begin{array}{l}15 \mathrm{MZ} \\
20 \mathrm{DZ}\end{array}$ & $\begin{array}{c}13 \mathrm{MZ} \\
8 \mathrm{DZ}\end{array}$ & $\begin{array}{l}33 \\
30\end{array}$ & $\begin{array}{r}8 \\
13\end{array}$ & $1 \cdot 1$ & 0.6 \\
\hline Pickens \& Svikis (1988) & $\begin{array}{l}40 \mathrm{MZ} \\
53 \mathrm{DZ}\end{array}$ & $\begin{array}{l}24 \mathrm{MZ} \\
22 \mathrm{DZ}\end{array}$ & $\begin{array}{l}70 \\
43\end{array}$ & $\begin{array}{l}29 \\
36\end{array}$ & 1.6 & 0.8 \\
\hline
\end{tabular}

occasion. Interestingly, those studies that examined the heritability of social consequences found no evidence for involvement of genetic factors. This finding provides evidence for the lack of validity of the definitions of alcoholism which depend upon social complications of drinking behaviour.

The results of four twin studies that assessed differential concordance between monozygotic and dizygotic twin pairs in which one member was identified through an alcoholism treatment programme are also shown in Table 3 . Concordance rates for monozygotic pairs ranged from 0.26 to 0.66 (average 0.39 ), whereas dizygotic pairs rates ranged from 0.12 to 0.39 (average 0.28 ). Three of the four studies found a two-fold increased risk among monozygotic $v$. dizygotic males. However, there was no evidence for increased concordance rates among monozygotic $v$. female dizygotic pairs. The lack of evidence for genetic factors in females may be partly attributed to the large degree of under-representation of female alcoholics in treatment samples and registries, differential exposure to alcohol in females, or the result of decreased drinking among co-twins of female alcoholic probands.

\section{Adoption studies}

There have been four major adoption studies of alcoholism, three of which yielded evidence for the role of genetic factors in the transmission of alcoholism (see Table 4). The latter three studies employed definitions of alcoholism which depended on severe behavioural and medical consequences of the use of alcohol, whereas the first study considered heavy drinking as the outcome of interest.

The results of the adoption studies constitute the major evidence to date favouring the role of transmissible genes in the aetiology of alcoholism. A summary of the four major adoption studies of alcoholism shows that the average relative risk of alcoholism in male adoptees with and without a family history of alcoholism is $2 \cdot 4$ and for female adoptees $2 \cdot 8$. There is a $2 \frac{1}{2}$ times greater chance of an adoptee developing alcoholism if a biological parent has alcoholism, irrespective of exposure to the alcoholic parent. In contrast to the family studies, there is some evidence for sex-specific transmission in some of the adoption studies of alcoholism.

Cloninger et al. (1981) have described two subtypes of alcoholism based upon the results of the Swedish adoption study by Bohman and colleagues (1981). The Type II predominantly male subtype is basically comprised of a heritable form of early onset heavy drinking with concomitant criminality or antisocial personality. In contrast, the Type I subtype, which is comprised of equal numbers of males and females with onset after the age of 25 , may be more likely to be associated with the major 'neurotic' psychiatric disorders including anxiety and depression syndromes. Based on these data, Cloninger (1987) has recently expounded a theory which integrates the dimensions of personality (i.e. novelty seeking, harm avoidance, and reward dependence), neurobiology and genetics in discriminating the two types of alcoholism. This theory has been incorporated into the designs of a large number of recent studies, which should generate data on the validity of the model and its components. 
Table 4. Adoption studies of alcoholism

\begin{tabular}{|c|c|c|c|c|}
\hline Site and authors & Numb & & $\begin{array}{c}\text { Alcoholism } \\
(\%)\end{array}$ & Relative risk \\
\hline Roe \& Burks (1945) & $\begin{array}{l}27 \\
27\end{array}$ & $\begin{array}{l}\text { Cases } \\
\text { Controls }\end{array}$ & $\begin{array}{l}70 \\
64\end{array}$ & $1 \cdot 1$ \\
\hline $\begin{array}{l}\text { Denmark } \\
\text { Goodwin et al. (1973) } \\
\text { Goodwin et al. (1977) }\end{array}$ & $\begin{array}{l}55 \\
70 \\
49 \\
48\end{array}$ & $\begin{array}{l}\text { Male cases } \\
\text { Controls } \\
\text { Female cases } \\
\text { Controls }\end{array}$ & $\begin{array}{r}18 \\
5 \\
4 \\
4\end{array}$ & $1 \cdot 0$ \\
\hline $\begin{array}{l}\text { USA } \\
\text { Cadoret et al. (1978) }\end{array}$ & $\begin{array}{r}6 \\
78 \\
127 \\
28 \\
87 \\
24\end{array}$ & $\begin{array}{l}\text { Cases } \\
\text { Controls } \\
\text { Male cases } \\
\text { Male controls } \\
\text { Female cases } \\
\text { Female controls }\end{array}$ & $\begin{array}{l}33 \\
1 \cdot 3 \\
61 \cdot 6 \\
23 \cdot 9 \\
33 \cdot 3 \\
5 \cdot 3\end{array}$ & $32 \cdot 0$ \\
\hline $\begin{array}{l}\text { Sweden } \\
\quad \text { Bohman et al. (1978) }\end{array}$ & $\begin{array}{r}89 \\
723 \\
42 \\
1029 \\
\\
29 \\
285 \\
22\end{array}$ & $\begin{array}{l}\text { Male adoptees } \\
\text { Alcoholic father } \\
\text { Controls } \\
\text { Alcoholic mother } \\
\text { Controls } \\
\text { Female adoptees } \\
\text { Alcoholic mother } \\
\text { Alcoholic father } \\
\text { Both alcoholic }\end{array}$ & $\begin{array}{l}39 \\
13 \\
29 \\
15\end{array}$ & $\begin{array}{l}3 \cdot 3 \\
1 \cdot 3 \\
3 \cdot 3\end{array}$ \\
\hline
\end{tabular}

The association between a biological alcoholic father and alcoholism in male offspring, irrespective of exposure to the biological father, has been confirmed in a 40-year longitudinal study of 456 men (Vaillant, 1980). The results of this study suggest that although paternal genetic background is an important predictor of the development of alcoholism in male offspring, an unstable childhood environment is a major predictor of age of onset and consequences of alcoholism.

\section{STUDIES OF ASSOCIATION AND LINKAGE}

Association or linkage between a known genetic marker and disease status comprises a major source of evidence regarding the involvement of genetic factors in the aetiology of a disease. There are a large number of reports of associations between alcoholism and biological factors, many of which are encoded by genes at known loci on particular chromosomes. Examples of the latter include colour blindness, a variety of serological markers including $\mathrm{ABO}, \mathrm{Rh}, \mathrm{MNS}, \mathrm{C} 3$, and HLA, palmar/finger prints, serum haptoglobin, phenylthiocarbamide (PTC) taste status, monoamine oxidase inhibition (MAOI), adenylate cyclase, and thyrotropin releasing hormone (TRH) challenge (Goodwin \& Guze, 1974). To date, however, none of these parameters constitute genetic markers for alcoholism for the following reasons: few of the parameters have been replicated in more than a single study; the parameters have often been found to return to normal after cessation of drinking; and no marker has been shown to be specific to alcoholism. A review of the concepts and methods for identifying phenotypic and genotypic biological markers in alcoholism is presented by RadoucoThomas et al. (1984).

Similarly, there is not a single study in which linkage between a known genetic marker and alcoholism has been conclusively demonstrated. Suggestive evidence has recently been presented by Hill et al. (1988), who reported a lod score of 2.02 at $\theta=0.007$ between the MNS locus on chromosome- 4 and alcoholism in 30 pedigrees, of which only about half were informative at this locus. The families were selected for 'pure' alcoholism with no concomitant psychiatric diagnoses 
in probands or relatives. However, ascertainment procedures of two ill and one well sibling per family precluded determination of the mode of inheritance and related parameters thereof. Interestingly, an association between the MN locus and alcoholism was also found in an earlier linkage study of serological markers and alcoholism by the primary author of the latter report (Hill et al. 1975).

In summary, despite the variability in sampling and methodology, the majority of the family, twin and adoption studies suggest that alcoholism is familial, and that a significant proportion of the familial aggregation can be attributed to genetic factors. However, the specific components of alcoholism that may be inherited have yet to be identified.

However, the variability in the degree of heritability, sex-specific transmission in the absence of evidence for an $X$-linked mode of transmission, indicate that the evidence is far from conclusive. This review demonstrates that a large degree of the above inconsistency may be attributed to methodological factors including variability in definitions of alcoholism, methods of selection of probands and collection of diagnostic information, and the lack of inclusion of controls within studies. A critical review of twin and adoption studies of alcoholism and recommendations for designs of future studies is discussed by Searles (1988).

\section{VULNERABILITY STUDIES}

The difficulty in disentangling antecedent markers from physiological consequences of ethanol has led to a focus on studies of individuals who are assumed to have increased vulnerability to alcoholism by virtue of the presence of a positive family history, particularly paternal alcoholism. Nearly all of the vulnerability studies have been based on a dichotomous classification of the presence or absence of a history of alcoholism in the antecedent generation. However, simulation studies have demonstrated that if a recessive model of transmission obtains for alcoholism, binomial classification leads to a misclassification of $50 \%$ of the families in which genes are operating as 'sporadic' (Goldin et al. 1987). Furthermore, the majority of the vulnerability studies also suffer from the important methodological limitation of the lack of direct interviews of the relatives of both the cases and controls in ascertaining the family history of alcoholism and other psychiatric conditions.

Despite the above limitations, there are a number of robust findings which suggest the presence of particular behavioural and biochemical precursors to alcoholism (Schuckit, 1987). The results of both retrospective and prospective studies converge in demonstrating that conduct disorder, hyperactivity, and attention deficit disorder appear to predispose to the development of alcoholism (Alterman \& Tarter, 1983). Deficits in performance on neuropsychological test batteries have been found consistently across studies, but no specific dysfunction indicative of a particular brain lesion or deficit has been identified (Hesselbrock et al. 1985). The most consistent behavioural precursor to alcoholism is impulsiveness, or low frustration tolerance (Knop et al. 1985). This trait could explain the generalized deficits in neuropsychological test performance, which would compromise the ability of the subject to complete the required study tasks.

The results of neurophysiological studies which provided evidence for decreased alpha power of the resting encephalogram (EEG) (Propping, 1977; Vogel \& Propping, 1981; Gabrielli et al. 1982; Pollock et al. 1983) and increased latency and decreased amplitude of the P-300 component of the evoked potential as possible markers for alcoholism have generated considerable excitement in the alcohol field during the last few years (Elmasian et al. 1982; Begleiter et al. 1984). This finding has been confirmed in several studies which have employed auditory tasks as well. However, the decrease in amplitude of the P-300 is dependent upon a number of factors including the individual characteristics of the sample and specific parameters of the task itself (Neville \& Schmidt, 1985; Polich \& Bloom, 1987; 1988; Polich et al. 1988 a, b; Hill et al. 1988). Additionally, the specificity of these abnormalities for alcoholism has not been assessed (Pfefferbaum et al. 1984; Strandburg et al. 1984).

One of the most consistent findings in studies of subjects at high risk for alcoholism is that they 
tend to have a less intensive subjective and objective response to alcohol under controlled conditions of administration than subjects without a familial history of alcoholism (Nathan \& Lipscomb 1979; Lipscomb \& Nathan, 1980; Schuckit, 1984). This suggests that a lack of tolerance may be protective against the development of alcoholism. Ironically, there is more information regarding those factors that protect against alcoholism than those that may have an aetiological role in its development.

The three major levels of enquiry regarding possible mechanisms for the transmission of alcoholism and the involvement of genes and gene products in its development are factors related to exposure, metabolism, or pharmacological effects of ethanol. Exposure to ethanol is an obvious precondition for the development of tolerance and/or dependence. Therefore, identification of factors which enhance (or decrease) exposure are important goals of studies of the pathogenesis of alcoholism. It is likely that demographic, cultural and environmental factors (i.e. sex, age, religious affiliation, social group influences, income, availability of alcohol, etc.) play a crucial role in mediating exposure to alcohol.

\section{STUDIES OF ALCOHOL-METABOLIZING GENES}

Variation in the metabolism of ethanol has been the most widely studied genetic factor in the alcohol field. Studies of normal twins have demonstrated high heritability for metabolic factors related to alcohol including the rate of absorption, degradation, and elimination of alcohol (Vesell et al. 1971). Interestingly, the consequences of alcohol use are the least heritable component of alcohol-related behaviour.

Recent identification of the genes involved in the metabolism of ethanol in humans has yielded information on the role of metabolism in the lack of tolerance to alcohol. The two major enzymes involved in the catabolism of ethanol are alcohol dehydrogenase (ADH), which converts ethanol to acetaldehyde; and aldehyde dehydrogenase (ALDH) which converts acetaldehyde to acetic acid. Approximately $75-90 \%$ of ethanol is metabolized via this pathway.

Table 5. Ethnic allelic frequencies for $A D H$ and $A L D H$

\begin{tabular}{|c|c|c|c|c|}
\hline & \multicolumn{3}{|c|}{ Frequency } & \multirow[b]{2}{*}{ Populations } \\
\hline & 1 & 2 & 3 & \\
\hline $\mathrm{ADH}_{2}$ & $\begin{array}{l}0.97 \\
0.95 \\
0.84 \\
0.33 \\
0.33\end{array}$ & $\begin{array}{r}0.03 \\
<0.05 \\
<0.05 \\
0.67 \\
0.67\end{array}$ & $\begin{array}{r}<0.05 \\
<0.05 \\
\\
0.16 \\
<0.05 \\
<0.05\end{array}$ & $\begin{array}{l}\text { Europeans } \\
\text { US Whites } \\
\text { US Blacks } \\
\text { Japanese } \\
\text { Chinese }\end{array}$ \\
\hline $\mathrm{ADH}_{3}$ & $\begin{array}{l}0.07 \\
0.50 \\
0.60 \\
0.64 \\
0.95 \\
0.97\end{array}$ & $\begin{array}{l}0.93 \\
0.50 \\
0.40 \\
0.36 \\
0.05 \\
0.09\end{array}$ & & $\begin{array}{l}\text { North American Indians } \\
\text { US Whites } \\
\text { Europeans } \\
\text { Asian-Indians } \\
\text { Japanese } \\
\text { Chinese }\end{array}$ \\
\hline $\mathrm{ALDH}_{1}$ & & $\begin{array}{l}\text { eficient } \\
38 \\
46 \\
5 \\
0 \\
0\end{array}$ & & $\begin{array}{l}\text { Oriental } \\
\text { South American Indians } \\
\text { North American Indians } \\
\text { Caucasians } \\
\text { Africans }\end{array}$ \\
\hline $\mathrm{ALDH}_{2}$ & & $\begin{array}{r}55 \\
42 \\
0-16 \\
0 \\
0\end{array}$ & & $\begin{array}{l}\text { Oriental } \\
\text { South American Indians } \\
\text { North American Indians } \\
\text { Caucasians } \\
\text { Black American }\end{array}$ \\
\hline
\end{tabular}


To date, three major classes of ADH genes have been identified, all of which are located on the long arm of chromosome-4. All of these genes exhibit tissue- and development-dependent expression. The three Class I ADH genes, alpha, beta, and gamma, have all been cloned, and have been demonstrated to be under hormonal control. Only two (i.e. ADH2, beta, and ADH3, gamma) of the five ADH genes have been shown to be polymorphic. Four ALDH genes have now been identified, of which three are polymorphic. The loci of ALDH1 and ALDH3 are $9_{\mathrm{q}}$ and 17 respectively. ALDH2 is mitochondrial and located on Chromosome-12 (reviewed by Smith, 1986; Duester et al. 1986).

The alcohol-metabolizing enzymes have revealed a remarkable degree of racial variation. The allelic frequencies for ADH and ALDH are shown in Table 5 (Holmes et al. 1986; Harada et al. 1983 a; Bosron et al. 1988). The 'atypical' $\mathrm{ADH}_{2}$ phenotype, which resulted from a single amino acid substitution, leads to a rapid build-up of acetaldehyde with 100 times greater specific activity than the normal phenotype. The abnormal $\mathrm{ALDH}_{1}$ and $\mathrm{ALDH}_{2}$ phenotypes, which are characteristic of Oriental populations, are derived from a single amino acid substitution. These phenotypes lead to an inability to convert acetaldehyde to acetic acid and produces the characteristic 'flushing' response to alcohol. Thus, the authors conclude that ALDH deficiencies are among the major genetic regulatory factors in alcohol consumption, and play a protective role against alcoholism.

The role of the alcohol-metabolizing genes as a protective influence on the development of alcoholism has been demonstrated by the results of a study which revealed that the majority of a group of hospitalized alcoholics in Japan possessed the normal enzyme variant for ALDH, whereas the controls' values approximated those of the general population (Harada et al. 1983 b). Despite these findings, neither ALDH nor ADH have been found to be associated with alcohol preference or tolerance in mice or humans. However, the recent availability of oligonucleotide clones of these genes will eliminate the necessity to conduct liver biopsies to characterize these enzymes and will facilitate studies of the role of the alcohol metabolizing enzymes in the pathogenesis of alcoholism (Hsu et al. 1985).

\section{SUMMARY}

Despite the variability in sampling and methodology, the majority of the family, twin and adoption studies suggest that alcoholism is familial, a significant proportion of which can be attributed to genetic factors. However, the specific components of alcoholism that may be inherited have yet to be identified. To date, there are no biological trait markers for which there is evidence for specificity for alcoholism.

The three major levels of enquiry regarding possible mechanisms for the transmission of alcoholism and the involvement of genes and gene products in its development are factors related to exposure, metabolism, or pharmacological effects of ethanol. Exposure to ethanol is an obvious precondition for the development of tolerance and/or dependence. Therefore, identification of factors which enhance (or decrease) exposure are important goals of studies of the pathogenesis of alcoholism. It is likely that demographic, cultural and environmental factors (i.e. sex, age, religious affiliation, social group influences, income, availability of alcohol, etc.) play a crucial role in mediating exposure to alcohol.

The key to alcoholism is likely to reside in the effects of alcohol on the brain. In contrast to nicotine, the opioids, and catecholamines, no specific receptor for ethanol has been found. Thus, one major focus of current research on possible central nervous system (CNS) mechanisms for the effect of alcohol includes assessment of the role of alcohol in the stimulation of brain reward or reinforcement systems. Alternately, alcohol may produce dependence by normalizing abnormal baseline states such as irritability, hyperexcitability, dysphoria, impulsiveness, or stress/tension level. The results of animal studies have yielded information on the central effects of alcohol including sensitivity of neuronal membranes, proteins, and ion channels to alcohol, and factors related to the binding and release of neurotransmitters and neuromodulators including dopamine, 
norepinephrine, gamma aminobutyric acid, pro-opiomelanocortin, glutamate receptors and the endorphin system (Institute of Medicine, 1987).

In addition to possible genetic explanations for the strong degree of familial aggregation of alcoholism, alternative explanations need to be further evaluated. These include: modelling of parental behaviour; possible changes in the susceptibility of the foetus to alcohol as a result of in utero maternal ingestion of alcohol; results of negligent rearing manifested in dietary deficiency, exposure to toxic substances, or brain trauma, which so often characterize the homes of alcoholic parents; or damage to paternal germ cells from alcohol.

\section{RECOMMENDATIONS FOR FUTURE STUDIES}

This review has identified several gaps in the research and methodology of genetic-epidemiological studies of alcoholism. The overriding problem in studies to date results from the lack of general agreement of a valid definition of alcoholism. The recent introduction of the ICD-10/DSM-III-R definitions, which focus on alcohol-seeking behaviour rather than its consequences, should reduce the sampling variability, which has led to discrepant and incomparable findings between studies. Future studies of the transmission of alcoholism should also incorporate the following methodological features in the study designs: careful selection of samples with attention to diagnostic accuracy and the role of ascertainment bias; selection of control groups which are comparable to the study group on all factors except the presence of alcoholism or its history in the family; employment of direct interviews of spouses and relatives to determine the phenotypes or relatives without knowledge of the phenotype of the proband; integration of comprehensive domains of assessment in order to evaluate the inter-relationships of risk factors and markers; assessment of the specificity of markers with respect to alcoholism by systematically including a group of non-alcoholic substance abuse or other appropriate controls; inclusion of measures of possible non-genetic transmissible factors; and evaluation of the components of alcohol-related behaviour rather than the broader concept of alcoholism.

Another integral step in assessing the genetics of alcoholism involves specification of the association between alcoholism and other psychiatric conditions and alternate types of substance abuse. Until the role of such co-morbid conditions is explicated, studies of the familial transmission of alcoholism will continue to produce conflicting results. More important, the power of studies of genetic linkage will be reduced by the lack of knowledge regarding the role of other related disorders in the co-transmission or as consequences of alcoholism. However, linkage studies may also comprise a valuable source of information for determining whether alcoholism and co-morbid conditions share similar underlying aetiological factors.

Concentration of research in two major areas is recommended: (l) large family studies with particular focus on hybrid twin/family or half-sibling/family study designs in order to: define the disorder of alcoholism, its subtypes, and its association with other psychiatric syndromes; to identify its mode(s) of inheritance; and to evaluate the transmission of the metabolic and neurobiological components of alcoholism; and (2) studies of the effects of alcohol on the brain via animal studies and neuroimaging studies of humans to identify the CNS effects of alcohol in which the aetiology of alcoholism is likely to reside.

KATHLEEN R. MERIKANGAS

This investigation was supported (in part) by United States Public Health Service, Alcohol, Drug Abuse and Mental Health Administration grants AA07080, DA50348; Yale Mental Health Clinical Research Center, National Institute of Mental Health Grant MH30929; and Research Scientist Development Award MH00499.

\section{REFERENCES}

Alterman, A. I. \& Tarter, R. E. (1983). The transmission of psychological vulnerability. Journal of Nervous and Mental Disease 171, 147-154.

Amark, C. (1951). A study in alcoholism. Acta Psychiatrica Scandinavica 70, (supplementum) 283.
American Psychiatric Association (1987). Diagnostic and Statistical Manual, 3rd Revision. Psychiatric Association Press: Washington, DC.

Begleiter, H., Porjesz, B. \& Bihari, B. (1984). Event-related brain potentials in boys at risk for alcoholism. Science 225, 1493-1496. 
Bleuler, M. (1955). Familial and personal background of chronic alcoholics. In Etiology of Chronic Alcoholism (ed. O. Diethelm), pp. 110-116. C. Thomas: Springfield, IL.

Bohman, M. (1978). Some genetic aspects of alcoholism and criminality: A population of adoptees. Archives of General Psychiatry 35, 269-276.

Bohman, M., Sigvardsson, S. \& Cloninger, C. R. (1981). Maternal inheritance of alcohol abuse. Archives of General Psychiatry 38, 965-969.

Bosron, W. F., Rex, D. K., Harden, C. A., Li, T. K. \& Akerson, R. D. (1988). Alcohol and aldehyde dehydrogenase isoenzymes in Sioux North American Indians. Alcoholism: Clinical and Experimental Research 12, 454-455.

Cadoret, R. \& Gath, A. (1978). Inheritance of alcoholism in adoptees. British Journal of Psychiatry 132, 252-258.

Cadoret, R., Cain, C. \& Grove, W. (1980). Development of alcoholism in adoptees raised apart from alcoholic biologic relatives. Archives of General Psychiatry 37, 561-563.

Cadoret, R. J., O'Gorman, T. W., Troughton, E. \& Haywood, E. (1985). Alcoholism and antisocial personality: interrelationships, genetic and environmental factors. Archives of General Psychiarry 42, 161-167.

Clifford, C. A., Hopper, J. L., Fulker, D. W. \& Murray, R. M. (1984). Genetic and environmental analysis of a twin family study of alcohol use, anxiety and depression. Genetic Epidemiology 1, 63-79.

Cloninger, C. R. (1987). Neurogenetic adaptive mechanisms in alcoholism. Science 236, 410-416.

Cloninger, C. R., Bohman, M. \& Sigvardsson, S. (1981). Inheritance of alcohol abuse. Archives of General Psychiatry 38, 861-868.

Cotton, N. S. (1979). The familial incidence of alcoholism. Journal of Studies on Alcohol 40, 89-116.

Duester, G., Smith, M. \& Bilanchone, V. (1986). Molecular analysis of the human class $l$ alcohol dehydrogenase gene family and nucleotide sequence of the gene encoding the beta subunit. Journal of Biological Chemistry 261, 2027-2033.

Edwards, S. G. \& Gross, M. M. (1976). Alcohol dependence; provisional description of a clinical syndrome. British Medical Journal I, 1058-1061.

Elmasian, R., Neville, H., Woods, D., Schuckit, M. \& Bloom, F. E. (1982). Event-related potentials are different in individuals at high and low risk for developing alcoholism. Proceedings of the National Academy' of Sciences of the United Siates of America 79, 7900-7903.

Gabrielli. W. F., Mednick, S. A., Volavka, J., Pollock, V. E., Schulsinger, F. \& Itil, T. M. (1982). Electroencephalograms in children of alcoholic fathers. Psychophysiology 19, 404-407.

Goldin, L. R., DeLisi, L. E. \& Gershon, E. S. (1987). Unravelling the relationship between genetic and environmental risk factors in psychiatric disorders. British Journal of Psychiatry 151, 302-305.

Goodwin, D. W. (1979). Alcoholism and heredity: A review and hypothesis. Archives of General Psychiatry 36, 57-61.

Goodwin, D. W. (1987). Genetic influences in alcoholism. Advances in Internal Medicine 32, 283-298.

Goodwin, D. W. \& Guze, S. (1974). Heredity and alcoholism. The Biology of Alcoholism, Vol. III: Clinical Pathology (ed. B. Kissin and H. Begleiter), pp. 37-52. Plenum Press: New York.

Goodwin, D. W., Schulsinger, F., Hermansen, L., Guze, S. D. \& Winokur, G. (1973). Alcohol problems in adoptees raised apart from alcoholic biological parents. Archives of General Psychiatry 28, 238-243.

Goodwin, D. W., Schulsinger, F., Knop, J., Mednick, S. \& Guze, S. D. (1977). Psychopathology in adopted and nonadopted daughters of alcoholics. Archives of General Psychiatry 34, 1005-1009.

Gurling, H. M. D., Murray, R. M. \& Clifford, C. A. (1981) Investigations into the genetics of alcohol dependence and into its effects on brain function. Twin Research 3: Epidemiologic Clinical Studies, pp. 77-87. Liss: New York.

Guze, S. B., Cloninger, C. R., Martin, R. \& Clayton, P. J. (1986). Alcoholism as a medical disorder. Comprehensive Psychiatry 27, 501-510.

Harada, S., Agarwal, D. P. \& Goedde, H. W. (1983). Aldehyde dehydrogenase: its genetic implication with alcoholism. In Biomedical Aspects of Alcohol and Alcoholism (ed. T. Kamade, K Kuriyama and H. S. Swaki), pp. 47-52. Amino Hospital Foundation, Gendaikikakushitsu Publishing: Japan.

Harada, S., Agarwal, D. P., Goedde, H. W. \& Ishikawa, B. (1983) Aldehyde dehydrogenase isoenzymes variation and alcoholism in Japan. Pharmacology and Biochentistry of Behavior 18, 151-153.

Helzer, J. E. \& Pryzbeck, T. R. (1983). The co-occurrence of alcoholism with other psychiatric disorders in the general population and its impact on treatment. Journal of Studies on Alcohol 49, 219-224.

Hesselbrock, V. M., Stabenau, J. R. \& Hesselbrock, M. N. (1985) Minimal brain dysfunction and neuropsychological test performance in offspring of alcoholics. In Recent Developments in Alcoholism, Vol.3 (ed. M. Galanter), pp. 65-82. Plenum Publishing Corporation: New York.

Hill, S. (1988). Event related potentials and other biologic markers in high risk three generation pedigrees. Presentation at the Research Society for Alcoholism, Annual Meeting, Symposium on the Genetics of Alcoholism, Wilu Dunes, North Carolina.

Hill, S. Y., Goodwin, D. W., Cadoret, R., Osterlund, C. R. \& Doner. S. M. (1975). Association and linkage between alcoholism and eleven serologic markers. Journal of Studies on Alcohol 36, 981-992,

Hill, S. Y., Aston, C. E. \& Rabin, B. (1988). Suggestive evidence between alcoholism and the MNS blood group. Alcoholism: Clinical and Experimental Research 12, 811-814.

Holmes, R. S., Duley, J. A., Algar, E. M., Mather, P. B. \& Ujjwal, K. R. (1986). Biochemical and genetic studies on enzymes of alcohol metabolism: the mouse as a model organism for human studies. Alcohol and Alcoholism 21, 41-56.

Hrubec, Z. \& Omenn, G. S. (1981). Evidence of genetic predisposition to alcoholic cirrhosis and psychosis: twin concordances for alcoholism and its biological end points by zygosity among mate veterans. Alcoholism: Clinical and Experimental Research 5, 207-215.

Hsu, L. C., Tani, K., Fujiyoshi, T., Kurachi, K. \& Yoshida, A. (1985). Cloning of cDNSs for human aldehyde dehydrogenases 1 and 2. Proceeding of the National Academy of Sciences of the United States of America 82, 3771-3775.

Institute of Medicine (1987). Causes and Consequences of Alcohol Problems. National Academy Press: Washington, DC.

Jacob, T. \& Bremer, D. A. (1986). Assortative mating among men and women alcoholics. Journal of Studies on Alcohol 47, 219-222.

Jonsson, A. \& Nilsson, T. (1968). Alkohol konsumption hos monozygota och dizygota tvillingar. Nordisk Hygienisk Tidskrift 49, $21-25$.

Kaij, L. (1960). Alcoholism in Twins. Almqvist and Wiksell: Stockholm.

Kaij, L. \& Dock, J. (1975). Grandsons of alcoholics. Archives of General Psychiatry 32, 1379-1381.

Kaprio, J., Koskenvuo, M. \& Sarna, S. (1981). Cigarette smoking, use of alcohol, and leisure-time physical activity among samesexed adult twins. Twin Research 3, Part C: Epidemiological and Clinical Studies, pp. 37-116. A. R. Liss: New York.

Kaprio, J., Koskenvuo, M., Langinvainio, H., Romanov, K., Sarna, S. \& Rose, R. J. (1987). Genetic influences on use and abuse of alcohol: a study of 5638 adult Finnish twin brothers. Alcoholism. Clinical and Experimental Research 11, 349-356.

Knop, J., Goodwin, D., Teasdale, T. W., Mikkelson, U. \& Schulsinger, F. (1984). A Danish prospective study of young males at high risk for alcoholism. In Longitudinal Research in Alcoholism (ed. D. W. Goodwin, Van Dusen, Teilmann and Mednick), pp. 107-122. Nijhoff: Boston.

Lipscomb, T. R. \& Nathan, P. E. (1980). Blood alcohol level discrimination: The effects of family history of alcoholism, drinking pattern, and tolerance. Archives of General Psychiatry 37, 571-577.

Loehlin, J. C. (1972). An analysis of alcohol-related questionnaire items from the National Merit Twin Study. Annals of the New York Academy of Sciences 197, 117-120.

Merikangas, K. R. (1982). Assortative mating for psychiatric disorders and psychological traits. Archives of General Psychiatry 39, $1173-1180$. 
Myers, J. K., Weissman, M. M., Tischler, G. L., Holzer, C. E., Leaf, P. J., Orvaschel, H., Anthony, J. C., Boyd, H. J., Burke, J. D., Kramer, M. \& Stoltzman, R. (1984). Six month prevalence of psychiatric disorders in three communities. Archives of General Psychiatry 41, 959-967.

Nathan, P. E. \& Lipscomb, T. R. (1979). Studies in blood alcohol level estimation: Etiologic cues to alcoholism. In Behavioral Analysis and Treatment of Substance Abuse (ed. N. Krasnegor), pp. 168-190. National Institute of Drug Abuse Monograph, Series No. 25, Alcohol, Drug Abuse, and Mental Health Administration: Rockville, Maryland.

Neville, H. J. \& Schmidt, A. L. (1985). Event-related brain potentials in subjects at risk for alcoholism. In Early Identification of Alcohol Abuse (ed. N. C. Chang and H. M. Chao), pp. 228-239. NIAAA Research Monograph, No. 7, DHHS Publication No (ADM) 85-1258, Government Printing Office: Washington.

O'Connor, S., Hesselbrock, V., Tasman, A. \& DePalma, N. (1977). P3 amplitudes in two distinct tasks are decreased in young men with a history of paternal alcoholism. Alcohol 4, 307-314.

Partanen, J., Bruun, K. \& Markkanen, T. (1966). Inheritance of Drinking Behavior: A Study of Intelligence, Personality, and Use of Alcohol in Adult Twins. The Finnish Foundation for Alcohol Studies, Pub. No. 14. The Finnish Foundation for Alcohol Studies: Helsinki.

Pederson, N. (1981). Twin similarity for usage of common drugs. In Twin Research 3: Epidemiological and Clinical Studies (ed. L. Gedda, P. Parisi and W. Nance), pp. 53-60. New York: Alan R. Liss: New York.

Pfefferbaum, A., Wenegrat, B. G., Ford, J. M., Roth, W. T. \& Kopell, B. S. (1984). Clinical application of the P3 component of event-related potentials. II. Dementia, depression, and schizophrenia. Electroencephalography and Clinical Neurophysiology 59, 104-124.

Pickens, R. W. \& Svikis, D. S. (1989). The Twin Method in the Study of Vulnerability to Drug Abuse. NIDA Research Monograph. National Institute of Drug Abuse, U.S. Government Printing Office: Washington, DC.

Pitts, F. N. Jr. \& Winokur, G. (1966). Affective disorder: VII. Alcoholism and affective disorder. Journal of Psychiatric Research 4, 37-50.

Polich, J. \& Bloom, F. E. (1987). P300 from normals and adult children of alcoholics. Alcohol 4, 301-305.

Polich, J. \& Bloom, F. E. (1988). Event-related potentials in individuals at high and low risk for developing alcoholism: Failure to replicate. Alcoholism: Clinical and Experimental Research 12, 368-373.

Polich, J., Burns, T. \& Bloom, F. E. (1988a). P300 and the risk of alcoholism: family history, task difficulty and gender. Alcoholism: Clinical and Experimental Research 12, 248-254.

Polich, J., Haier, R. J., Buchsbaum, M. S. \& Bloom, F. E. (1988 b). Assessment of young men at risk for alcoholism with $P 300$ from a visual discrimination task. Journal of Studies on Alcohol 49, 186-190.

Pollock, V. E., Volavka, J., Goodwin, D. W., Mednick, S. A., Gabrielli, W. F., Knop, J. \& Schulsinger, F. (1983). The EEG after alcohol administration in men at risk for alcoholism. Archives of General Psychiatry 40, 857-861.

Propping, P. (1977). Genetic control of ethanol action on the central nervous system. An EEG study in twins. Human Genetics 35, 309-334.
Radouco-Thomas, S., Gaicin, F., Murthy, M. R. V., Faure, N., Lemay, A., Forest, J. C. \& Radouco-Thomas, C. (1984). Biological markers in major psychosis and alcoholism: Phenotypic and genotypic markers. Journal of Psychiatric Research 18, 513-539.

Reich, T., Rice, J., Cloninger, C. R. \& Lewis, C. (1980). The contribution of affected parents to the pool of affected individuals: Path analysis of the segregation distribution for alcoholism. In The Social Consequences of Psychiatric Illness (ed. L. N. Robins, P. J. Clayton, and J. K. Wing), pp. 91-113. Brunner/Mazel: New York.

Reich, T., Winokur, G. \& Mullaney, J. (1975). The transmission of alcoholism. In Genetic Research in Psychiatry (ed. R. R. Fieve, D. Rosenthal, and H. Brill), pp. 259-269. Johns Hopkins: Baltimore. Robins, L. N., Helzer, J. E., Weissman, M. M., Orvaschel, H., Gruenberg, E., Burke, J. \& Regier, D. A. (1984). Lifetime prevalence of specific psychiatric disorders in three sites. Archives of General Psychiatry 41, 949-958.

Roe, A. \& Burks, B. (1945). Adull Adjustment of Foster-Children of Alcoholic and Psychotic Parentage and the Influence of the FosterHome. Memoirs of the Section on Alcohol Studies, No. 3. Yale University Press: New Haven, CT.

Schuckit, M. (1984). Subjective response to alcohol in sons of alcoholics and controls. Archives of General Psychiatry 41, 879-884.

Schuckit, M. (1986) Biological vulnerability to alcoholism. Journal of Consulting and Clinical Psychology 55, 301-309.

Schuckit, M., Goodwin, D. \& Winokur, G. (1972). A study of alcoholism in half-siblings. American Journal of Psychiatry 128, 122-125.

Searles, J. S. (1988). The role of genetics in the pathogenesis of alcoholism. Journal of Abnormal Psychology 97, 153-167.

Shapiro, S., Skinner, E. A., Kessler, L. G., Von Korff, M., German, P. S., Tischler, G. L., Leaf, P. J., Benham, L. B., Cottler, L. and Regier, D. A. (1984). Utilization of health and mental health services. Archives of General Psychiatry 41, 971-982.

Smith, M. (1986). Genetics of human alcohol and aldehyde dehydrogenases. Advances in Human Genetics 15, 249-290.

Strandburg, R. J., Marsh, J. T., Brown, W. S., Asarnow, R. F. \& Guthrie, D. (1984). Event-related potentials concomitants of information processing dysfunction in schizophrenic children. Electroencephalography and Clinical Neurophysiology 57, 236-253.

Vailliant, G. E. (1980). Natural history of male psychological health: VIII Antecedents of alcoholism and orality. American Journal of Psychiarry 137, 181-186.

Vesell, E. S., Page, J. F. \& Passananti, G. T. (1971). Genetic and environmental factors affecting ethanol methabolism in man. Clinical Pharmacology and Therapeutics 12, 192.

Vogel, F. \& Propping, P. (1981). The Electroencephalogram (EEG) as a research tool in human behavior genetics. In Genetic Research Strategies for Psychobiology and Psychiatry (ed. E. S. Gershon, S. Matthysse, X. O. Breakefield and R. D. Ciaranello), pp. 269-280. Boxwood Press: Pacific Grove.

Warheit, G. (1987). The epidemiology of alcoholism. In Psychiatry. (ed. R. Michels and J. Cavenar), pp. 1-18. J. B. Lippincott: Philadelphia.

Warner, R. H. \& Rossett, H. L. (1975). The effects of drinking on offspring: An historical survey of the American and British literature. Journal of Studies on Alcohol 36, 1395-1420. 